\title{
A Informação como Direito do Consumidor ${ }^{4}$
}

\author{
Fernanda Nunes Barbosa
}

\section{RESUMO}

Este trabalho tem como objetivo apresentar um panorama do direito à informação nas relações de consumo, partindo da análise da importância assumida pela informação como valor social No âmbito da defesa do consumidor, esse direito adquire ainda maior relevância, uma vez que o desequilibrio informativo se torna evidente, com reflexos não só na esfera econômica dos sujeitos, senão também na esfera pessoal. Nesse sentido, o direito à informação será tratado, no presente estudo, na perspectiva de um direito fundamental.

O direito básico do consumidor à informação, positivado, no Código de Defesa do Consumidor brasileiro, no art. $6^{\circ}$, inc. III, unido à previsão constitucional da defesa do consumidor e do direito fundamental à informação constituem a base legal paza o desenvolvimento da jurisprudência nacional na matéria, que será igualmente objero de exame.

Como dever imposto aos fornecedores, a informação pode constituir tanto um dever principal como um dever anexo, que encontra, no principio da boa-fé, a fonte primordial para sua imposição. Ao lado da boa-fé objetiva, serão examinados, ainda, o ideal de transparência no mercado de consumo e os deveres de proteção, quando se destacará o papel instrumental do dever de informar.

Em una apreciação mais detalhada da lei especial, enfatizaremos o estabelecimento dos deveres de informar como prevenção de danos, bem como nas declarações de vontade.

\footnotetext{
4 à Banca Examinadora composta pelo Professor Doutor Luís Renako Fetreint da Siha, Professor da Pontficia Universidade Católica do Rio Grande do Sul e Doutor em Direito Civil peja Universidade de São Paulo, e pela Professora Doutora Rosângela Lumantelli Cavatharzti, Professora da Universictade Estadual do Rio de Janeiro, Doutora em Direito Civil pela Universidade Federal do Rio de Janeiro, e pelo Professor Doutor José Alcebiades de Olituina Júnior, Professor Tinular da Universidade Federal do Rio Grande do Sul, Doutor pela Universidade Federal de Santa Catarina. A referida banca de defesa de dissertação foi presidida pela Professora Doutora Cláudia Lima Marques, Professora Titular da Universidade Federal do Rio Grande do Sul e Doutora em Direito pela Universidade de Heidelberg - Alemanha, orientadora do referito trabalho.
} 